\title{
Dickkopf-3 in Human Malignant Tumours: A Clinical Viewpoint
}

\author{
EUN-JU LEE ${ }^{1}$, QUE THANH THANH NGUYEN ${ }^{1}$ and MOOYUL LEE ${ }^{2}$ \\ ${ }^{1}$ Department of Obstetrics and Gynecology and ${ }^{2}$ Departement of Physiology, \\ Chung-Ang University School of Medicine, Seoul, Republic of Korea
}

\begin{abstract}
Dickkopf-3 (DKK3), also known as REIC, is a secreted glycoprotein. DKK3 is aberrantly expressed in various types of human malignant tumours. Promoter methylation status, intracellular protein expression, and protein expression in tumour vessels are significantly correlated with clinical prognostic factors, including survival. In malignant cells, DKK3 is involved in the induction of apoptosis, inhibition of invasion, and remodelling of tumour vasculature. These activities are carried out via the regulation of the beta-catenin signalling and c-Jun N-terminal kinase-dependent cellular pathway, both of which are critical for carcinogenesis. This review explores the potential value of DKK3 as a clinical biomarker and a therapeutic candidate in human malignancies.
\end{abstract}

Dickkopf-3 (DKK3) was discovered to be down-regulated in immortalized cells although, originally, the gene was identified as REIC (1). Since then, the intracellular expression of DKK3 was evaluated in various types of malignant tissues and was found to be down-regulated in cancer cells unlike in normal cells. It has been shown that the reduced expression of DKK3 is mainly mediated by hypermethylation of the promoter region. This aberrant expression or promoter methylation status was also associated with prognostic clinical factors, including survival, suggesting the potential relevance of DKK3 as a clinical biomarker in human malignancies.

This article is freely accessible online.

Correspondence to: Eun-Ju Lee (ORCID: 0000-0001-9446-1059), $\mathrm{MD}, \mathrm{PhD}$, Department of Obstetrics and Gynecology, Chung-Ang University School of Medicine/Chung-Ang University Hospital, 102 Heuksuk-Ro, Dongjak-Gu, Seoul, 06973, Republic of Korea. Tel: +82 262991648, Fax: +82 262632187, e-mail: ejlee@cau.ac.kr

Key Words: Dickkopf-3, clinical biomarker, malignant tumour, therapeutics, review.
According to its sequence homology, DKK3 belongs to the DKK family of proteins, which consists of DKK1-4, secreted glycoproteins with two cysteine-rich domains, and Soggy (2, $3)$. DKK1, -2 , and -4 negatively regulate the Wnt signalling pathway by directly interacting with Wnt coreceptors $(3,4)$, however, the role of DKK3 in Wnt signalling is not clear. It has been shown that DKK3 is associated with $\beta$-catenin and c-Jun N-terminal kinase (JNK)-dependent signalling, the pathway critical for the progression of cancer. Furthermore, the tumour-suppressive activities of DKK3 have been demonstrated in a variety of cancers.

In the present review, we summarize the clinical significance, cellular functions, and intracellular signalling pathways related to DKK3, and highlight the potential of DKK3 as a therapeutic target and clinical tumour biomarker.

\section{Aberrant Expression of DKK3 in Malignant Tumours}

DKK3 is aberrantly expressed in human malignant cells unlike in normal cells. The intracellular down-regulation of DKK3 has been reported in 40.5 to $76.6 \%$ of malignant tumours that originate in the prostate, colon and rectum, breast, uterine cervix, ovaries, endometrium, lungs, stomach, kidney, and bladder, as well as in leukaemias, testicular cancers, and malignant melanomas (5-26) (Table I). These findings indicate that the down-regulation of DKK3 could be an essential event in carcinogenesis. Interestingly, DKK3 can also be overexpressed in a few malignant tumours, such as oesophageal adenocarcinoma with moderate to high DKK3 expression in $46.8 \%$ of the cases compared to $20 \%$ in Barrett's metaplasia (27), oral squamous cell carcinoma with higher DKK3 protein expression in $84.3 \%$ versus $22.5 \pm 16.5 \%$ in normal specimens (28), and hepatoblastoma with DKK3 overexpressed in 11/14 cases compared to non-cancerous parenchyma (29). These differences in aberrant expression patterns may be explained by tumour or tissue context-dependent variations and tissue type-specific biology; however, further studies are required to understand the exact mechanisms. 
Table I. Clinical significance of aberrant expression/promoter hypermethylation of DKK3 in human malignant tissues.

\begin{tabular}{|c|c|c|c|c|c|c|c|}
\hline \multirow[t]{2}{*}{ Human cancer } & \multicolumn{2}{|c|}{ Down-regulation } & \multicolumn{2}{|c|}{ Promoter methylation } & \multicolumn{2}{|c|}{ Clinical significance(s) } & \multirow[t]{2}{*}{ Reference } \\
\hline & $\%$ (number) & Method & $\%$ (number) & Method & $\begin{array}{l}\text { Correlated } \\
\text { clinical factors }\end{array}$ & $\begin{array}{l}\text { Survival } \\
\text { correlation }\end{array}$ & \\
\hline Bladder cancer & $\begin{array}{c}\text { Lower quantitative } \\
\text { level in } \\
\text { tumour }(\mathrm{N}=24)\end{array}$ & RT-PCR & $70.8(17 / 24)$ & MSP & Tumour invasion & - & $\begin{array}{l}\text { Urakami et al. } \\
2006(23)\end{array}$ \\
\hline \multirow[t]{2}{*}{$\begin{array}{l}\text { Basal breast } \\
\text { cancer }\end{array}$} & $\begin{array}{l}\text { Lower median } \\
\text { IRS (N=463) }\end{array}$ & IHC & & & $\begin{array}{l}\text { Triple-negative, } \\
\text { HER2 positive, } \\
\text { luminal subtype }\end{array}$ & & $\begin{array}{l}\text { Lorsy et al. } \\
2016 \text { (14) }\end{array}$ \\
\hline & $\begin{array}{l}\text { Low vs. high level } \\
\text { of mRNA }(\mathrm{N}=3554)\end{array}$ & $\begin{array}{l}\text { In silico } \\
\text { analysis }\end{array}$ & & & & $\begin{array}{l}\text { Lower recurrence- } \\
\text { free survival }\end{array}$ & \\
\hline Breast cancer & & & $78(75 / 96)$ & MSP & $\begin{array}{l}\text { Higher clinical } \\
\text { stage, LN } \\
\text { involvement, } \\
\text { ER positive }\end{array}$ & - & $\begin{array}{l}\text { Xiang et al. } \\
2013 \text { (35) }\end{array}$ \\
\hline Breast cancer & & & $61.3(92 / 150)$ & MSP & Older age & $\begin{array}{c}\text { Lower overall } \\
\text { survival* }\end{array}$ & $\begin{array}{l}\text { Veeck et al. } \\
2009 \text { (47) }\end{array}$ \\
\hline Cervical cancer & $64.8(57 / 88)$ & $\mathrm{IHC}$ & & & $\begin{array}{c}\text { Higher FIGO } \\
\text { stage }\end{array}$ & $\begin{array}{c}\text { Lower disease-free } \\
\text { survival* }\end{array}$ & $\begin{array}{l}\text { Ryu et al. } \\
2013 \text { (16) }\end{array}$ \\
\hline Cervical cancer & & & $\begin{array}{c}\text { Higher quantitative } \\
\text { level in } \\
\text { tumour }(\mathrm{N}=62)\end{array}$ & $\begin{array}{c}\text { Pyro- } \\
\text { sequencing }\end{array}$ & $\begin{array}{l}\text { Higher level of SCC } \\
\text { tumour marker, } \\
\text { bigger tumour size }\end{array}$ & - & $\begin{array}{l}\text { Kang et al. } \\
2013 \text { (43) }\end{array}$ \\
\hline Cervical cancer & & & $38(38 / 100)$ & MSP & $\begin{array}{l}\text { Higher FIGO stage, } \\
\text { LN involvement }\end{array}$ & $\begin{array}{l}\text { Lower overall } \\
\text { survival* }\end{array}$ & $\begin{array}{l}\text { Zhang et al. } \\
2018 \text { (41) }\end{array}$ \\
\hline Colorectal cancer & $70.1(228 / 325)$ & $\mathrm{IHC}$ & & & $\begin{array}{l}\text { Invasion depth, } \\
\text { higher TNM stage, } \\
\text { dedifferentiation }\end{array}$ & No correlation & $\begin{array}{l}\text { Wang et al. } \\
2012(6)\end{array}$ \\
\hline Colorectal cancer & & & $52.3(67 / 128)$ & MSP & - & No correlation & $\begin{array}{l}\text { Yu et al. } \\
2009 \text { (34) }\end{array}$ \\
\hline Colorectal cancer & & & $21(12 / 58)$ & MSP & No correlation & - & $\begin{array}{l}\text { Sato et al. } \\
2007(48)\end{array}$ \\
\hline Endometrial cancer & $\begin{array}{c}\text { r Quantitative } \\
\text { analysis }(\mathrm{N}=27)\end{array}$ & RT-PCR & & & $\begin{array}{l}\text { Higher FIGO stage, } \\
\text { LN involvement, } \\
\text { non-endometrioid } \\
\text { histology, cytology- } \\
\text { positive }\end{array}$ & - & $\begin{array}{c}\text { Dellinger et al } \text {. } \\
2012(15)\end{array}$ \\
\hline Gastric cancer & $40.5(64 / 158)$ & $\mathrm{IHC}$ & & & $\begin{array}{l}\text { Higher TNM stage, } \\
\text { LN involvement, }\end{array}$ & $\begin{array}{l}\text { Lower disease- } \\
\text { free survival }\end{array}$ & $\begin{array}{l}\text { Park et al. } \\
2015 \text { (26) }\end{array}$ \\
\hline Gastric cancer & $63.9(236 / 369)$ & $\mathrm{IHC}$ & & & $\begin{array}{l}\text { Younger age, bigger } \\
\text { tumour size, } \\
\text { LN involvement, } \\
\text { Lauren's classification }\end{array}$ & Lower survival & $\begin{array}{l}\text { Xu et al. } \\
2012(25)\end{array}$ \\
\hline Gastric cancer & & & $67.6(117 / 173)$ & MSP & Higher TNM stage & $\begin{array}{l}\text { Lower overall } \\
\text { survival, increased } \\
\text { risk of cancer- } \\
\text { related death* }\end{array}$ & $\begin{array}{l}\text { Yu et al. } \\
2009 \text { (34) }\end{array}$ \\
\hline Gastric cancer & & & $39(12 / 31)$ & MSP & No correlation & - & $\begin{array}{l}\text { Sato et al. } \\
2007 \text { (48) }\end{array}$ \\
\hline $\mathrm{HCC}$ & & & $\begin{array}{c}\text { Quantitative } \\
\text { analysis }(\mathrm{N}=50)\end{array}$ & $\begin{array}{l}\text { Quantitative } \\
\text { MSP }\end{array}$ & Multicentricity & $\begin{array}{l}\text { Lower progression- } \\
\text { free survival* }\end{array}$ & $\begin{array}{l}\text { Yang et al. } \\
2010 \text { (42) }\end{array}$ \\
\hline \multirow[t]{2}{*}{ ALL } & & & $33(60 / 183)$ & MSP & No correlation & $\begin{array}{l}\text { Lower disease- } \\
\text { free survival* }\end{array}$ & $\begin{array}{l}\text { Roman-Gomez } \\
\text { et al. } 2004 \text { (22) }\end{array}$ \\
\hline & $38.4(70 / 183)$ & RT-PCR & & & & & \\
\hline NSCLC & $63(36 / 57)$ & RT-PCR & & & $\begin{array}{l}\text { Higher tumour } \\
\text { grade }\end{array}$ & $\begin{array}{l}\text { No } \\
\text { correlation }\end{array}$ & $\begin{array}{c}\text { Nozaki et al. } \\
2001 \text { (18) }\end{array}$ \\
\hline NSCLC & $76.6(72 / 94)$ & $\mathrm{IHC}$ & & & $\begin{array}{l}\text { Higher tumour } \\
\text { grade }\end{array}$ & - & $\begin{array}{l}\text { Yue et al. } \\
2008 \text { (17) }\end{array}$ \\
\hline
\end{tabular}


Table I. Continued

\begin{tabular}{|c|c|c|c|c|c|c|c|}
\hline \multirow[t]{2}{*}{ Human cancer } & \multicolumn{2}{|c|}{ Down-regulation } & \multicolumn{2}{|c|}{ Promoter methylation } & \multicolumn{2}{|c|}{ Clinical significance(s) } & \multirow[t]{2}{*}{ Reference } \\
\hline & $\%$ (number) & Method & $\%$ (number) & Method & $\begin{array}{c}\text { Correlated } \\
\text { clinical factors }\end{array}$ & $\begin{array}{l}\text { Survival } \\
\text { correlation }\end{array}$ & \\
\hline NSCLC & & & $16.3(22 / 135)$ & MSP & No correlation & $\begin{array}{l}\text { Lower overall } \\
\text { survival* }\end{array}$ & $\begin{array}{l}\text { Suzuki et al. } \\
2007 \text { (39) }\end{array}$ \\
\hline NSCLC & & & $14.2(22 / 155)$ & MSP & No correlation & No correlation & $\begin{array}{l}\text { Zhu et al. } \\
2012(40)\end{array}$ \\
\hline Ovarian cancer & $66(37 / 56)$ & $\mathrm{IHC}$ & & & No correlation & - & $\begin{array}{l}\text { You et al. } \\
2011 \text { (19) }\end{array}$ \\
\hline Prostate cancer & $\begin{array}{c}47.1(8 / 17, \mathrm{G} 3) \\
52.9(14 / 25, \mathrm{G} 4) \\
71.4(5 / 7, \mathrm{G} 5)\end{array}$ & $\mathrm{IHC}$ & & & $\begin{array}{l}\text { High Gleason } \\
\text { grade }(\mathrm{G})\end{array}$ & - & $\begin{array}{c}\text { Kawano et al. } \\
2006 \text { (79) }\end{array}$ \\
\hline Prostate cancer & & & $68(28 / 41)$ & MSP & - & - & $\begin{array}{c}\text { Lodygin et al } \text {. } \\
2005 \text { (37) }\end{array}$ \\
\hline Renal cancer & $\mathrm{N}=64$ & $\begin{array}{c}\text { IHC, } \\
\text { RT-PCR }\end{array}$ & & & No correlation & & $\begin{array}{l}\text { Guo et al. } \\
2014 \text { (20) }\end{array}$ \\
\hline Renal cancer & & & $50(31 / 62)$ & MSP & $\begin{array}{l}\text { Higher tumour } \\
\text { grade }\end{array}$ & $\begin{array}{l}\text { Lower overall } \\
\text { survival }\end{array}$ & $\begin{array}{c}\text { Urakami et al } \\
2006(24)\end{array}$ \\
\hline \multirow[t]{2}{*}{ Human cancer } & \multicolumn{3}{|c|}{ Up-regulation } & & \multicolumn{2}{|c|}{ Clinical significance, correlation with } & Reference \\
\hline & $\%$ (number) & Method & & & $\begin{array}{l}\text { Correlated } \\
\text { clinical factors }\end{array}$ & $\begin{array}{l}\text { Survival } \\
\text { correlation }\end{array}$ & \\
\hline $\begin{array}{l}\text { Oesophageal } \\
\text { cancer }\end{array}$ & $\begin{array}{c}\text { Quantitative } \\
\text { analysis }(n=94)\end{array}$ & RT-PCR & & & $\begin{array}{l}\text { Higher stage, } \\
\text { LN involvement }\end{array}$ & - & $\begin{array}{l}\text { Wang et al. } \\
2015 \text { (27) }\end{array}$ \\
\hline
\end{tabular}

RT-PCR: Real time reverse transcriptional polymerase chain reaction; MSP: methylation specific polymerase chain reaction; LN: lymph node; ER: oestrogen receptor; IRS: immunoreactive score; IHC: immunohistochemistry; HER2: human epidermal growth factor receptor 2; FIGO: International Federation of Gynecology and Obstetrics; SCC, squamous cell carcinoma; TNM: tumour node metastasis; HCC: hepatocellular carcinoma; ALL: acute lymphoblastic leukaemia; NSCLC: non-small cell lung cancer. *Shown by multivariate analysis.

DKK3 is identified as a tumour endothelial marker, as is significantly up-regulated in the blood vessels of malignant colorectal tissues (30). Furthermore, DKK3 was found to be up-regulated in tumour endothelial cells (ECs) in $56 \%$ of 318 colorectal cancer tissue samples. DKK3-positive colorectal cancer is also significantly associated with higher mean microvessel count than DKK3-negative colorectal cancer samples, as well as with an increase in the number of intratumoural microvessels per sample (31). Furthermore, the number of blood vessels expressing DKK3 is increased in glioma, high-grade non-Hodgkin's lymphoma, and melanoma (32). Therefore, these findings suggest that DKK3 is involved in neovascularization and could be used as a marker for neoangiogenesis.

\section{Epigenetic Inactivation by Methylation of the $D K K 3$ Promoter}

Investigation of the mechanisms responsible for the decreased $D K K 3$ expression in human cancers revealed epigenetic inactivation by hypermethylation of the $D K K 3$ promoter based on the following findings. 1) the $D K K 3$ gene is located on chromosome 11p15, a target of methylation-medicated genetic imprinting (33); 2) silenced or reduced mRNA expression of $D K K 3$ is closely associated with promoter methylation (8); 3) the occurrence of hypermethylation in the promoter leads to the down-regulation of $D K K 3$, whereas this down-regulation in the silenced cancer cell lines can be reversed by inhibiting DNA-methyltransferase activity with 5-Aza-dC and trichostatin A $(9,34-36)$.

As expected, up to $78 \%$ promoter methylation of $D K K 3$ is detected in various malignant tissue samples (Table I) $(8,9$, 22-24, 34-41). The quantitative methylation level of $D K K 3$ in cancer tissues is significantly higher than that in controls, and studies have revealed a threshold of quantitative methylation levels that facilitates prognosis prediction (Table I) $(38,42$, 43). Taken together, the promoter methylation of $D K K 3$ is a highly frequent phenomenon and is causally related to the down-regulation of $D K K 3$ during carcinogenesis.

$D K K 3$ methylation in circulating free DNA from blood was investigated using methylation-specific polymerase chain reaction (MSP). Interestingly, 37 out of 112 patients 
with breast cancer (33\% sensitivity in breast cancer) were positive for DKK3 methylation, while 101 out of 102 normal controls (99\% specificity in normal controls) were negative (44). Similarly, DKK3 methylation was found in $27.3 \%$ (9/33) of serum DNA from renal cancer patients, and $100 \%$ of normal individuals were negative for methylated $D K K 3$ in their serum (24). Furthermore, $D K K 3$ methylation could also be found in urine from patients with bladder tumours: $50 \%$ of patient samples were positive (12/24 urine samples), whereas $95 \%$ of normal controls (19/20 urine samples) were negative for $D K K 3$ methylation (23). These findings suggest that DKK3 may be useful as a blood-based or a body-fluid based biomarker in certain types of cancers.

\section{Clinical Implications of $D K K 3$ Down-regulation or Epigenetic Silencing}

The association of DKK3 down-regulation in tumour cells with negative clinical outcomes has been demonstrated in several cancers (Table I). For example, in breast cancer, DKK3 downregulation is more common in patients with triple-negative or human epidermal growth factor receptor 2-positive breast cancer subgroups. Furthermore, the analysis of a large in silico dataset $(3,554$ cases) showed that low DKK3 mRNA expression has a significant association with a reduction in recurrence-free survival in luminal and basal-like breast cancer cases (14). In cervical cancer, the down-regulation of DKK3 is associated with higher International Federation of Gynecology and Obstetrics (FIGO) stage and lower disease-free survival rates (16). Patients with down-regulated DKK3 in their colorectal cancer cells show deeper invasion, higher TNM stages, and dedifferentiation, which are poor prognostic factors (6). In endometrial cancer, reduced $D K K 3$ mRNA expression is associated with higher FIGO stage, lymph node involvement, non-endometrioid histology, and washing cytology positivity (15). Gastric cancer patients with loss of $D K K 3$ present with aggressive clinical factors, including higher TNM stage, lymph node involvement, and poorer survival than those with normal DKK3 levels $(25,26)$. Lung cancer patients with loss of DKK3 in cancer tissues exhibit higher tumour grades than patients with no loss of DKK3 $(17,18)$. On the other hand, protein down-regulation in ovarian and renal cancers has no clinical significance $(19,20)$ a whereas in oesophageal cancers with increased levels of DKK3 mRNA present has a higher stage and lymph node involvement (27). Taken together, the intracellular aberrant expression of DKK3 can be used as a biomarker to predict poor prognosis, an additional tool for precision medicine before the initiation of treatment.

Interestingly, the clinical significance of DKK3 expression in the tumour endothelium in colorectal, gastric, and pancreatic cancers is not clear. DKK3 positivity in tumour ECs is significantly associated with higher mean microvessel count and worse disease-free survival in colorectal cancer than in DKK3-negative tumours (31). In contrast, in gastric and pancreatic cancers, patients with strong DKK3 expression in the tumour endothelium or with high intratumour microvessel density had significantly better survival $(45,46)$.

As DKK3 down-regulation has clear clinical significance, hypermethylation of the $D K K 3$ promoter has potential functional consequences (Table I). In bladder cancer, a high proportion of methylated $D K K 3$ was found in invasive cancers rather than in superficial cancers (23). In breast cancer, it has been shown that $D K K 3$ methylation has a significant correlation with a higher clinical stage, lymph node involvement, and oestrogen receptor-positive status, but not with survival (35). At the same time, using multivariate analysis, others reported a significant correlation between $D K K 3$ methylation and shorter survival rates in breast cancer patients, including disease-free survival and overall survival in patients (47). Comparative quantitative methylation profiling using pyrosequencing or quantitative MSP found a methylation threshold that was associated with survival in patients with cervical cancer and hepatocellular carcinoma; furthermore, this threshold increased the prediction value of disease recurrence when analyzed with clinical factors $(42,43)$. A multivariate analysis of 104 patients out of 173 with gastric cancers demonstrated that patients with $D K K 3$ promoter methylation had significantly higher TNM stage and worse survival than patients without $D K K 3$ methylation (34). Acute lymphoblastic leukaemia patients with methylated $D K K 3$ also showed lower disease-free survival than patients with unmethylated $D K K 3$ (22). In non-small cell lung cancer, $D K K 3$ methylation was significantly correlated with lower overall survival, as determined by multivariate analysis (39). Furthermore, $D K K 3$ methylation has been found predominantly in higher grade or advanced stages of renal cancer, rather than in lower grade or earlier stages, and was associated with worse overall survival (24). In contrast, no significant differences were observed in two clinical analyses of patients with colorectal cancer $(34,48)$. Overall, these results suggest that aberrant methylation status and a quantitative threshold of DKK3 have important functional roles in cancer patient prognosis and could, therefore, be used as a clinical biomarker.

\section{Single Nucleotide Polymorphisms (SNPs) in DKK3}

SNPs are single base changes in a DNA sequence. Germ-line differences in $D K K 3$ SNPs between cancerous and normal cases have been identified $(9,49-56)$. The effects of DKK3 SNPs on disease susceptibility have been investigated in several cancers. In a study of 272 cases and 173 controls, SNPs rs12421658, rs11022105, and rs4586138 were found to be associated with prostate cancer risk, whereas SNPs rs2087882 and rs1472190 were associated with prostate cancer aggressiveness, including serum levels of prostatespecific antigen, clinical stage, pathological stage, and Gleason 
score (49). In a study of 210 patients with renal cell carcinoma and 200 age- and sex-matched controls, SNP rs3206824 was associated with a decreased risk of renal cancer and cancerrelated deaths (50). In a study of 99 patients with breast cancer and 93 controls, women with the GG genotype in the SNP rs6485350 of $D K K 3$ were found to have a 2-fold reduced risk of breast cancer and protection against oestrogen receptorpositive tumours compared to women with the AA genotype (51). A study of 732 ovarian cancer cases and 765 controls in a Northern Chinese population, the AA genotype, but not the GG genotype, in the SNP rs6485350 of DKK3 was associated with significantly reduced risk of ovarian cancer (52). Furthermore, in a study of 300 lung cancer cases and 300 controls in north Indians, the genotype combination of $D K K 3$ rs3206824 and DKK2 rs419558 was 2-fold higher in lung cancer patients, and was associated with an increased risk of developing lung cancer (53). In contrast, no significant association was observed in patients with uterine cervical, gastric, colorectal and lung cancer $(9,54-56)$. These findings suggest that $D K K 3$ SNPs may predict susceptibility to prostate, renal, breast and ovarian cancer; however, further large-scale studies are needed to confirm these results.

\section{DKK3 Is a Tumour Suppressor}

As DKK3 expression is typically reduced in cancer cells, the effect of DKK3 on apoptosis, migration, invasion, and angiogenesis in cancer cells has been investigated. Most studies have demonstrated the anti-proliferative activity of DKK3 in osteosarcoma, colon cancer, gastric cancer, glioma, prostate cancer, uterine cervical cancer, malignant melanoma, hepatic, non-small cell lung cancer, and breast cancer $(3,9$, $12,17,34,35,37,48,57-60)$.

Interestingly, normal cells are protected from DKK3mediated cell death. In a study using adenovirus to express DKK3 in various cancer and non-cancerous cell lines, apoptotic cell death was observed only in cancer cells, and not in normal cells $(7,13)$, suggesting that DKK3-mediated apoptosis might be a selective cancer-specific feature despite the presence of some resistant tumour cells. Therefore, the knowledge of the selective apoptosis-inducing mechanisms may be useful for identifying DKK3-responsive cancers and could help establish novel pharmacological targets to resensitize resistant tumour cells.

It has been reported that the forced expression of $D K K 3$ in Saos-2 osteosarcoma cells significantly alters their cellular morphology from an irregularly shaped and spread, to a round-shaped, compact, attached, and less motile (61). Ectopic DKK3 expression in melanoma cells and mesenchymal basal breast cancer cells results in changes in cellular morphology facilitating cell-to-cell contact, up-regulation of the epithelial marker E-cadherin, and down-regulation of the mesenchymal marker Snail-1 (12, 14, 35, 62). Through its association with the epithelial-to-mesenchymal transition (EMT), DKK3 expression reduces cellular invasion and motility $(12,61,63)$, whereas $D K K 3$ silencing by small interfering RNA increases invasion capacity (10). Therefore, DKK3 is involved in the EMT and its loss could promote the aggressive properties of cancer cells.

DKK3 has anti-proliferative activity in drug-resistant cancer cells. In cisplatin-resistant lung cancer cells, DKK3 increases cisplatin sensitivity, whereas $D K K 3$ knockdown decreases the sensitivity of cells to cisplatin. These mechanisms are related to the down-regulation of $\beta$-catenin, which has well-documented roles in chemoresistance (64). Doxorubicin-resistant breast cancer cells express abundant P-glycoprotein; in these cells, DKK3 induces apoptosis via down-regulation of P-glycoprotein, which plays a role in drug efflux, augmenting the multidrug-resistance of cancer cells and cell survival in response to anticancer drugs (65). Therefore, DKK3 blocks drug resistance mechanisms and its increased expression could enhance drug sensitivity.

\section{DKK3 Is Involved in Tumour Angiogenesis}

Growing tumours require blood supply to meet the elevated need for oxygen and nutrients; therefore, tumours stimulate surrounding stromal tissue to produce novel blood vessels (66). Tumour angiogenesis is a hallmark of most malignancies. Because of the differences between the tumour-associated endothelium in abnormal microvessels and the normal endothelium, it is possible to target only the tumour associated endothelium. Unlike in normal blood vessels, DKK3 was positive in tumour vessels of colorectal cancer, glioma, high-grade non-Hodgkin's lymphomas, melanoma, gastric cancer, prostatic cancer, pancreatic cancer, and oesophageal adenocarcinoma $(5,12,27,32,45,46)$. DKK3 overexpression has no effect on the proliferation and migration of ECs; however, it enhanced tube formation capacity in Matrigel assays in vitro and microvessel density in vivo. Conversely, DKK3 knockout inhibited endothelial tube formation. Furthermore, DKK3 may facilitate the remodelling of tumour vasculature by differentiating tumoural ECs. The overexpression of DKK3 directly promotes the differentiation of human fibroblasts into functional ECs, with fibroblast-derived ECs capable of forming microvascular tubular structures in tissue-engineered vascular grafts ex vivo (67). Furthermore, DKK3 may also act as a chemokine by binding to the $\mathrm{C}-\mathrm{X}-\mathrm{C}$ chemokine receptor type 7 and triggering downstream signalling pathways involved in vascular progenitor migration and vascular regeneration (68). Taken together, DKK3 may be a putative pro-angiogenesis factor in vascularization and a potential marker of neo-angiogenesis. However, the exact mechanisms for DKK3 up-regulation in the tumour endothelium remain unclear. 


\section{Intracellular Signalling of DKK3}

Wnt signalling. Wnt signalling regulates a wide range of physiological processes, including embryonic development, cell proliferation, stem cell maintenance, and epithelialmesenchymal interactions, and is also linked to human carcinogenesis (69). DKKs are known to antagonize Wnt signalling pathways (4); however, DKK3 has been shown not to affect Wnt signalling in various assays, such as Wntdependent secondary axis induction in Xenopus embryos and Wnt/Fz8 signalling in cultured cells (70-73).

To antagonize Wnt signalling, DKKs are known to directly interact with WNT receptors. It has been shown that DKK1, 2 , and -4 bind to and internalize LRP5/6, the membrane coreceptors involved in canonical Wnt signalling $(3,71,74)$; however, DKK3 does not interact with LRP5/6 (73). Furthermore, DKK1, -2 , and -4 directly interact with the transmembrane protein Kremen, expressed on the cell surface (73-75); however, DKK3 does not interact with Kremen either (74). Instead, DKK3 colocalizes with Kremen-1 at the intracellular membranous compartments, such as the Golgi apparatus or the endoplasmic reticulum, leading to potentiation of Wnt-3A signalling (76). Because this interaction occurs in the membrane vesicles, the cellular surface membrane interaction partners of secreted DKK3 still have not been identified, and further studies are needed to elucidate how this type of interaction between DKK3 and Kremen influences the Wnt/ $\beta$-catenin signalling pathway. In addition, DKK3 inhibits Wnt-7A signalling in pheochromo-cytoma PC12 cells, although this effect is weak and occurs only in the presence of both LRP5 and -6 (77). Therefore, further studies are needed to elucidate the connection between DKK3 and the Wnt signalling pathway.

DKK3 is involved in the inactivation of $\beta$-catenin. Although the effects of DKK3 on the Wnt signalling pathway have not yet been identified, it has been shown that DKK3 facilitates the degradation of $\beta$-catenin in glioma, cervical cancer, breast cancer, and osteosarcoma cells $(9,17,35,57,61)$. For example, DKK3 inhibits Tcf/Lef luciferase activity triggered by $\beta$-catenin, whereas $\beta$-catenin/TCF- 4 signalling is activated in DKK3 knockouts $(9,17)$. DKK3 is also involved in the proteasomal degradation of $\beta$-catenin by direct interaction with $\beta$-transducin repeat protein, which first recognizes and targets phosphorylated $\beta$-catenin for ubiquitination (78). Moreover, DKK3 inhibits gene expression downstream of $\beta$ catenin, including genes encoding VEGF and cyclin D1 (9). Furthermore, there is a statistically significant inverse correlation between DKK3 expression and nuclear $\beta$-catenin expression (11). For example, by attenuating $\beta$-catenin, DKK3 induces apoptosis in cisplatin-resistant lung adenocarcinoma cells (64). Taken together, these findings suggest that DKK3 plays a role in inhibiting $\beta$-catenin signalling, potentially through a Wnt-independent pathway.
DKK3 is involved in caspase-dependent JNK activation. One mechanism of DKK3-mediated apoptosis involves caspasedependent JNK activation without $\beta$-catenin $(7,79)$. DKK3 induces endoplasmic reticulum stress, which, in turn, triggers the activation of JNK. JNK activation induces mitochondrial translocation of Bax without any changes in protein levels (7). In breast, prostate, and lung cancers, DKK3 induces apoptosis through early JNK phosphorylation and subsequent caspase-9 and -3 cleavage $(7,60,65)$. In contrast, in malignant glioma cells, DKK3 induces apoptosis via caspase- 3 cleavage by caspase-9, not by caspase-8; however, JNK does not appear to play a crucial role (57). Therefore, DKK3 can promote cell type-specific caspase-dependent apoptosis via JNK activation.

The upstream regulators of DKK3. The pathways upstream of DKK3 have not been fully elucidated. The knockdown of membrane type-1 matrix metalloproteinase up-regulates $D K K 3$ mRNA levels via transcriptional activation (63). The tumour suppressor GATA4, down-regulated in ovarian cancer, hepatocellular carcinoma, and colorectal cancer (80), directly binds to the promoter region of $m i R-125 b$ and inhibits its expression. $D K K 3$ is a direct target of $m i R-125 b$; therefore, GATA4 enhances $D K K 3$ expression by blocking the transcription of $m i R-125 b(81)$. On the other hand, the tumourpromoting E2 factor transcription factor 3 (E2F3), the transcription factor involved in gastric cancer progression, regulates the $m i R-125 a / D K K 3$ axis by binding to the promoter of $m i R-125$. Overexpressed E2F3 directly augments $m i R-125 a$ expression, resulting in suppression of $D K K 3$ (82).

Other pathways. DKK3 directly binds to small glutamine-rich tetratricopeptide repeat-containing protein a (SGTA), a component of the androgen receptor (AR) complex and the negative modulator of cytoplasmic AR signalling (83). Cytoplasmic DKK3 inhibits SGTA function by interfering with SGTA dimerization. Furthermore, the suppression of AR signalling by SGTA can be rescued by increased DKK3 expression in prostate cancer cells. Therefore, DKK3 binds to SGTA and plays a physiological role in the regulation of AR signalling. Down-regulation of DKK3 may be associated with decreased androgen insensitivity in prostate cancer cells.

\section{Gene Therapy With DKK3}

Since DKK3 acts as a tumour suppressor, augmentation of $D K K 3$ expression using therapeutic gene approaches has been studied. Adenovirus-mediated induction of $D K K 3$ (Ad-DKK3) gene therapy can inhibit tumour growth or sensitize cancerous cells to undergo apoptosis in prostate, breast, testicular cancer, malignant mesothelioma, pancreatic cancer, malignant glioma, scirrhous gastric carcinoma, bladder cancer, and biliary cancer cells $(7,84-91)$, whereas this effect is attenuated in normal cells $(7,85,86,92)$. Furthermore, Ad-DKK3 gene therapy may 
enhance anticancer immunity, by activating or differentiating immune cells to induce apoptosis not only at the tumour-treated site, but also at other distant cancer lesions $(92,93)$. Besides, Ad-DKK3 increases the secretion of IL-7, which activates natural killer cells to induce anticancer immunity $(92,94,95)$.

Due to the suppression of DKK3 associated with aberrant promoter methylation, the clustered regularly interspaced short palindromic repeats (CRISPR)-Cas9 system targeting specific epigenetic alterations of $D K K 3$ has been used in prostate cancer. In these experiments, CRISPR-Cas9 was used to target either the transcriptional activators or catalytic domain of the demethylase Tet1 in the DKK3 promoter, leading to increased DKK3 mRNA and protein levels, and resulting in decreased prostate cell proliferation and migration (96). Therefore, $D K K 3$-based gene therapy could be a potential therapeutic tool for cancer treatment; however, additional experiments are required to further confirm this therapeutic potential.

\section{Conclusion}

Here, we summarize the latest findings regarding the potential applications of DKK3 as a clinical biomarker to be used in precision medicine to predict cancer prognosis and drug responsiveness. Furthermore, DKK3 may also act as a biomarker for neovascularization. Further prospective clinical trials using large independent cohorts are necessary to establish DKK3 as an actual biomarker in the clinical setting.

The intrinsic mechanisms of secreted DKK3 still remain elusive, since the putative cell surface receptor has not been identified. Elucidating the specific intracellular signalling cascades activated by DKK3-receptor binding will facilitate the development of DKK3-dependent therapeutics.

\section{Conflicts of Interest}

All of the Authors declare that they have no conflicts of interest in relation to this study.

\section{Authors' Contributions}

Lee EJ drafted the manuscript; Nguyen Q and Lee M prepared the figures and drafted the figure legends.

\section{Acknowledgements}

This study was supported by the Basic Science Research Program through the National Research Foundation of Korea (NRF) under Grant number 2020R1A2C1003536.

\section{References}

1 Tsuji T, Miyazaki M, Sakaguchi M, Inoue Y and Namba M: A reic gene shows down-regulation in human immortalized cells and human tumor-derived cell lines. Biochem Biophys Res Commun 268(1): 20-24, 2000. PMID: 10652205. DOI: trans 10.1006/bbrc.1999.2067
2 Krupnik VE, Sharp JD, Jiang C, Robison K, Chickering TW, Amaravadi L, Brown DE, Guyot D, Mays G, Leiby K, Chang B, Duong T, Goodearl AD, Gearing DP, Sokol SY and McCarthy SA: Functional and structural diversity of the human dickkopf gene family. Gene 238(2): 301-313, 1999. PMID: 10570958. DOI: $10.1016 / \mathrm{s} 0378-1119(99) 00365-0$

3 Veeck $\mathrm{J}$ and Dahl E: Targeting the wnt pathway in cancer: The emerging role of dickkopf-3. Biochim Biophys Acta 1825(1): 1828, 2012. PMID: 21982838. DOI: 10.1016/j.bbcan.2011.09.003

4 Klaus A and Birchmeier W: Wnt signalling and its impact on development and cancer. Nat Rev Cancer 8(5): 387-398, 2008. PMID: 18432252. DOI: $10.1038 / \mathrm{nrc} 2389$

5 Zenzmaier C, Untergasser G, Hermann M, Dirnhofer S, Sampson N and Berger P: Dysregulation of dkk-3 expression in benign and malignant prostatic tissue. Prostate 68(5): 540-547, 2008. PMID: 18247400 . DOI: 10.1002/pros.20711

6 Wang W, Zhu W, Xu XY, Nie XC, Yang X, Xing YN, Yu M, Liu YP, Takano Y and Zheng HC: The clinicopathological significance of reic expression in colorectal carcinomas. Histol Histopathol 27(6): 735-743, 2012. PMID: 22473694. DOI: 10.14670/hh-27.735

7 Abarzua F, Sakaguchi M, Takaishi M, Nasu Y, Kurose K, Ebara S, Miyazaki M, Namba M, Kumon H and Huh NH: Adenovirusmediated overexpression of reic/dkk-3 selectively induces apoptosis in human prostate cancer cells through activation of c-jun-nh2-kinase. Cancer Res 65(21): 9617-9622, 2005. PMID: 16266978. DOI: $10.1158 / 0008-5472$.CAN-05-0829

8 Veeck J, Bektas N, Hartmann A, Kristiansen G, Heindrichs U, Knuchel R and Dahl E: Wnt signalling in human breast cancer: Expression of the putative wnt inhibitor dickkopf-3 (dkk3) is frequently suppressed by promoter hypermethylation in mammary tumours. Breast Cancer Res 10(5): R82, 2008. PMID: 18826564. DOI: $10.1186 / \mathrm{bcr} 2151$

9 Lee EJ, Jo M, Rho SB, Park K, Yoo YN, Park J, Chae M, Zhang $\mathrm{W}$ and Lee JH: Dkk3, downregulated in cervical cancer, functions as a negative regulator of beta-catenin. Int J Cancer 124(2): 287297, 2009. PMID: 19003969. DOI: 10.1002/ijc.23913

10 Maehata T, Taniguchi H, Yamamoto H, Nosho K, Adachi Y, Miyamoto N, Miyamoto C, Akutsu N, Yamaoka S and Itoh F: Transcriptional silencing of dickkopf gene family by cpg island hypermethylation in human gastrointestinal cancer. World J Gastroenterol 14(17): 2702-2714, 2008. PMID: 18461655. DOI: 10.3748/wjg.14.2702

11 Mazieres J, He B, You L, Xu Z and Jablons DM: Wnt signaling in lung cancer. Cancer Lett 222(1): 1-10, 2005. PMID: 15837535. DOI: $10.1016 /$ j.canlet.2004.08.040

12 Kuphal S, Lodermeyer S, Bataille F, Schuierer M, Hoang BH and Bosserhoff AK: Expression of dickkopf genes is strongly reduced in malignant melanoma. Oncogene 25(36): 5027-5036, 2006. PMID: 16568085. DOI: 10.1038/sj.onc.1209508

13 Tanimoto R, Abarzua F, Sakaguchi M, Takaishi M, Nasu Y, Kumon $\mathrm{H}$ and Huh NH: Reic/dkk-3 as a potential gene therapeutic agent against human testicular cancer. Int J Mol Med 19(3): 363-368, 2007. PMID: 17273781.

14 Lorsy E, Topuz AS, Geisler C, Stahl S, Garczyk S, von Stillfried S, Hoss M, Gluz O, Hartmann A and Knüchel R: Loss of dickkopf 3 promotes the tumorigenesis of basal breast cancer. PloS One 11(7): e0160077, 2016. PMID: 27467270. DOI: 10.1371/journal.pone.0160077

15 Dellinger TH, Planutis K, Jandial DD, Eskander RN, Martinez ME, $\mathrm{Zi} \mathrm{X,} \mathrm{Monk} \mathrm{BJ} \mathrm{and} \mathrm{Holcombe} \mathrm{RF:} \mathrm{Expression} \mathrm{of} \mathrm{the} \mathrm{wnt} \mathrm{antagonist}$ 
dickkopf-3 is associated with prognostic clinicopathologic characteristics and impairs proliferation and invasion in endometrial cancer. Gynecol Oncol 126(2): 259-267, 2012. PMID: 3688285. DOI: 10.1016/j.ygyno.2012.04.026

16 Ryu SW, Kim JH, Kim MK, Lee YJ, Park JS, Park HM, Kim $\mathrm{DH}$, Lee $\mathrm{SH}$ and Lee EJ: Reduced expression of dkk3 is associated with adverse clinical outcomes of uterine cervical squamous cell carcinoma. Int J Gynecol Cancer 23(1): 134-140, 2013. PMID: 23154266. DOI: 10.1097/IGC.0b013e3182754feb

17 Yue W, Sun Q, Dacic S, Landreneau RJ, Siegfried JM, Yu J and Zhang L: Downregulation of dkk3 activates beta-catenin/tcf-4 signaling in lung cancer. Carcinogenesis 29(1): 84-92, 2008. PMID: 18048388. DOI: 10.1093/carcin/bgm267

18 Nozaki I, Tsuji T, Iijima O, Ohmura Y, Andou A, Miyazaki M, Shimizu N and Namba M: Reduced expression of reic/dkk-3 gene in non-small cell lung cancer. Int J Oncol 19(1): 117-121, 2001. PMID: 11408931. DOI: 10.3892/ijo.19.1.117

19 You A, Fokas E, Wang LF, He H, Kleb B, Niederacher D, Engenhart-Cabillic R and An HX: Expression of the wnt antagonist $\mathrm{dkk} 3$ is frequently suppressed in sporadic epithelial ovarian cancer. J Cancer Res Clin Oncol 137(4): 621-627, 2011. PMID: 20532910. DOI: 10.1007/s00432-010-0916-6

20 Guo CC, Zhang XL, Yang B, Geng J, Peng B and Zheng JH: Decreased expression of $\mathrm{dkk} 1$ and $\mathrm{dkk} 3$ in human clear cell renal cell carcinoma. Mol Med Rep 9(6): 2367-2373, 2014. PMID: 24676838. DOI: 10.3892/mmr.2014.2077

21 Horikawa Y, Watanabe M, Sadahira T, Ariyoshi Y, Kobayashi Y, Araki M, Wada K, Ochiai K, Li SA and Nasu Y: Overexpression of reic/dkk-3 suppresses the expression of cd147 and inhibits the proliferation of human bladder cancer cells. Oncol Lett 14(3): 3223-3228, 2017. PMID: 28927069. DOI: $10.3892 / \mathrm{ol} .2017 .6548$

22 Roman-Gomez J, Jimenez-Velasco A, Agirre X, Castillejo J, Navarro G, Barrios M, Andreu EJ, Prosper F, Heiniger A and Torres A: Transcriptional silencing of the dickkopfs-3 (dkk-3) gene by cpg hypermethylation in acute lymphoblastic leukaemia. Br J Cancer 91(4): 707-713, 2004. PMID: 15226763. DOI: 10.1038/sj.bjc.6602008

23 Urakami S, Shiina H, Enokida H, Kawakami T, Kawamoto K, Hirata H, Tanaka Y, Kikuno N, Nakagawa M and Igawa M: Combination analysis of hypermethylated wnt-antagonist family genes as a novel epigenetic biomarker panel for bladder cancer detection. Clin Cancer Res 12(7): 2109-2116, 2006. PMID: 16609023. DOI: 10.1158/1078-0432.CCR-05-2468

24 Urakami S, Shiina H, Enokida H, Hirata H, Kawamoto K, Kawakami T, Kikuno N, Tanaka Y, Majid S and Nakagawa M: Wnt antagonist family genes as biomarkers for diagnosis, staging, and prognosis of renal cell carcinoma using tumor and serum DNA. Clin Cancer Res 12(23): 6989-6997, 2006. PMID: 17145819. DOI: 10.1158/1078-0432.CCR-06-1194

25 Xu X-y, Xia P, Yu M, Nie X-c, Yang X, Xing Y-n, Liu Y-p, Takano $\mathrm{Y}$ and Zheng H-c: The roles of reic gene and its encoding product in gastric carcinoma. Cell Cycle 11(7): 14141431, 2012. PMID: 22421143. DOI: 10.4161/cc.19823

26 Park JM, Kim MK, Chi KC, Kim JH, Lee SH and Lee EJ: Aberrant loss of dickkopf-3 in gastric cancer: Can it predict lymph node metastasis preoperatively? World J Surg 39(4): 1018-1025, 2015. PMID: 25604390. DOI: 10.1007/s00268-014-2886-3

27 Wang Z, Lin L, Thomas DG, Nadal E, Chang AC, Beer DG and Lin J: The role of dickkopf-3 overexpression in esophageal adenocarcinoma. J Thorac Cardiovasc Surg 150(2): 377-385. e372, 2015. PMID: 26093488. DOI: 10.1016/j.jtcvs.2015.05.006

28 Fujii M, Katase N, Lefeuvre M, Gunduz M, Buery RR, Tamamura $\mathrm{R}$, Tsujigiwa $\mathrm{H}$ and Nagatsuka H: Dickkopf (dkk)-3 and $\beta$-catenin expressions increased in the transition from normal oral mucosal to oral squamous cell carcinoma. J Mol Histol 42(6): 499, 2011. PMID: 21932035. DOI: 10.1007/s10735-011-9357-Z

29 Pei Y, Kano J, Iijima T, Morishita Y, Inadome Y and Noguchi M: Overexpression of dickkopf 3 in hepatoblastomas and hepatocellular carcinomas. Virchows Arch 454(6): 639-646, 2009. PMID: 19437037. DOI: 10.1007/s00428-009-0772-4

30 St Croix B, Rago C, Velculescu V, Traverso G, Romans KE, Montgomery E, Lal A, Riggins GJ, Lengauer C, Vogelstein B and Kinzler KW: Genes expressed in human tumor endothelium. Science 289(5482): 1197-1202, 2000. PMID: 10947988. DOI: 10.1126/science.289.5482.1197

31 Zitt M, Untergasser G, Amberger A, Moser P, Stadlmann S, Zitt M, Muller HM, Muhlmann G, Perathoner A, Margreiter R, Gunsilius E and Ofner D: Dickkopf-3 as a new potential marker for neoangiogenesis in colorectal cancer: Expression in cancer tissue and adjacent non-cancerous tissue. Dis Markers 24(2): 101-109, 2008. PMID: 18219095. DOI: 10.1155/2008/160907

32 Untergasser G, Steurer M, Zimmermann M, Hermann M, Kern J, Amberger A, Gastl G and Gunsilius E: The dickkopf-homolog 3 is expressed in tumor endothelial cells and supports capillary formation. Int J Cancer 122(7): 1539-1547, 2008. PMID: 18033687. DOI: $10.1002 /$ ijc. 23255

33 Pfeifer K: Mechanisms of genomic imprinting. Am J Hum Genet 67(4): 777-787, 2000. PMID: 10986038. DOI: 10.1086/303101

34 Yu J, Tao Q, Cheng YY, Lee KY, Ng SS, Cheung KF, Tian L, Rha SY, Neumann U and Röcken C: Promoter methylation of the wnt/ $\beta$-catenin signaling antagonist dkk-3 is associated with poor survival in gastric cancer. Cancer 115(1): 49-60, 2009. PMID: 19051296. DOI: 10.1002/cncr.23989

35 Xiang T, Li L, Yin X, Zhong L, Peng W, Qiu Z, Ren G and Tao Q: Epigenetic silencing of the wnt antagonist dickkopf 3 disrupts normal wnt/beta-catenin signalling and apoptosis regulation in breast cancer cells. J Cell Mol Med 17(10): 1236-1246, 2013. PMID: 23890219. DOI: 10.1111/jcmm.12099

36 Liang L, He H, Lv R, Zhang M, Huang H, An Z and Li S: Preliminary mechanism on the methylation modification of dkk1 and dkk-3 in hepatocellular carcinoma. Tumour Biol 36(2): 1245-1250, 2015. PMID: 25344678. DOI: 10.1007/s13277-0142750-y

37 Lodygin D, Epanchintsev A, Menssen A, Diebold J and Hermeking H: Functional epigenomics identifies genes frequently silenced in prostate cancer. Cancer Res 65(10): 42184227, 2005. PMID: 15899813. DOI: 10.1158/0008-5472.CAN04-4407

38 Ding Z, Qian Y-B, Zhu L-X and Xiong Q-R: Promoter methylation and mrna expression of dkk-3 and wif-1 in hepatocellular carcinoma. World J Gastroenterol 15(21): 25952601, 2009. PMID: 19496188. DOI: 10.3748/wjg.15.2595

39 Suzuki M, Shigematsu H, Nakajima T, Kubo R, Motohashi S, Sekine Y, Shibuya K, Iizasa T, Hiroshima K, Nakatani Y, Gazdar $\mathrm{AF}$ and Fujisawa T: Synchronous alterations of wht and epidermal growth factor receptor signaling pathways through aberrant methylation and mutation in non small cell lung cancer. Clin Cancer Res 13(20): 6087-6092, 2007. PMID: 17947472. DOI: 10.1158/1078-0432.CCR-07-0591 
40 Zhu J, Wang Y, Duan J, Bai H, Wang Z, Wei L, Zhao J, Zhuo M, Wang S, Yang L, An T, Wu M and Wang J: DNA methylation status of wnt antagonist sfrp5 can predict the response to the egfr-tyrosine kinase inhibitor therapy in non-small cell lung cancer. J Exp Clin Cancer Res 31(1): 80, 2012. PMID: 3524045. DOI: $10.1186 / 1756-9966-31-80$

41 Zhang M, Huang M, Cao B, Sheng X and Li P: Methylation of the $\mathrm{dkk} 3$ promoter is associated with poor prognosis in patients with cervical adenocarcinoma. Int J Clin Exp Pathol 11(2): 788, 2018. PMID: 31938166.

42 Yang B, Du Z, Gao YT, Lou C, Zhang SG, Bai T, Wang YJ and Song WQ: Methylation of dickkopf-3 as a prognostic factor in cirrhosis-related hepatocellular carcinoma. World J Gastroenterol 16(6): 755-763, 2010. PMID: 20135726. DOI: 10.3748/wjg. v16.i6.755

43 Kang WS, Cho SB, Park JS, Lee MY, Myung SC, Kim WY, Lee SH, Kim DH and Lee EJ: Clinico-epigenetic combination including quantitative methylation value of dkk3 augments survival prediction of the patient with cervical cancer. J Cancer Res Clin Oncol 139(1): 97-106, 2013. PMID: 22961207. DOI: 10.1007/s00432-012-1262-7

44 Kloten V, Becker B, Winner K, Schrauder MG, Fasching PA, Anzeneder T, Veeck J, Hartmann A, Knuchel R and Dahl E: Promoter hypermethylation of the tumor-suppressor genes itih5, dkk3, and rassf1a as novel biomarkers for blood-based breast cancer screening. Breast Cancer Res 15(1): R4, 2013. PMID: 23320751. DOI: $10.1186 / \mathrm{bcr} 3375$

45 Mühlmann G, Untergasser G, Zitt M Zitt M, Maier H, Mikuz G, Kronberger I, Haffner M, Gunsilius E, Ofner D: Immunohistochemically detectable dickkopf-3 expression in tumor vessels predicts survival in gastric cancer. Virchows Arc 456(6): 635-646, 2010. PMID: 20473620. DOI: 10.1007/s00428-0100926-4

46 Fong D, Hermann M, Untergasser G, Pirkebner D, Draxl A, Heitz M, Moser P, Margreiter R, Hengster P and Amberger A: Dkk-3 expression in the tumor endothelium: A novel prognostic marker of pancreatic adenocarcinomas. Cancer Sci 100(8): 1414-1420, 2009. PMID: 19493271. DOI: 10.1111/j.1349-7006.2009.01208.x

47 Veeck J, Wild PJ, Fuchs T, Schuffler PJ, Hartmann A, Knuchel $\mathrm{R}$ and Dahl E: Prognostic relevance of wnt-inhibitory factor-1 (wif1) and dickkopf-3 (dkk3) promoter methylation in human breast cancer. BMC Cancer 9: 217, 2009. PMID: 19570204. DOI: $10.1186 / 1471-2407-9-217$

48 Sato H, Suzuki H, Toyota M, Nojima M, Maruyama R, Sasaki S, Takagi H, Sogabe Y, Sasaki Y, Idogawa M, Sonoda T, Mori $\mathrm{M}$, Imai $\mathrm{K}$, Tokino $\mathrm{T}$ and Shinomura $\mathrm{Y}$ : Frequent epigenetic inactivation of dickkopf family genes in human gastrointestinal tumors. Carcinogenesis 28(12): 2459-2466, 2007. PMID: 17675336. DOI: $10.1093 /$ carcin/bgm178

49 Kim MS, Lee HN, Kim HJ and Myung SC: Single nucleotide polymorphisms in $\mathrm{dkk} 3$ gene are associated with prostate cancer risk and progression. Int Braz J Urol 41(5): 869-897, 2015. PMID: 26689513. DOI: 10.1590/S1677-5538.IBJU.2014.0041

50 Hirata H, Hinoda Y, Nakajima K, Kikuno N, Yamamura S, Kawakami K, Suehiro Y, Tabatabai ZL, Ishii N and Dahiya R: Wnt antagonist gene polymorphisms and renal cancer. Cancer 115(19): 4488-4503, 2009. PMID: 19562778. DOI: $10.1002 /$ cncr.24491

51 Alanazi MS, Parine NR, Shaik JP, Alabdulkarim HA, Ajaj SA and Khan Z: Association of single nucleotide polymorphisms in wnt signaling pathway genes with breast cancer in saudi patients. PloS One 8(3): e59555, 2013. PMID: 23516639. DOI: 10.1371/journal.pone.0059555

52 An JD, Zhao YL, Yu LB, Wang HW, Jin CM, Wang Y, Zhao HT and Sun BC: Association between snps in wnt signaling pathway genes and ovarian cancer risk in northern chinese population. Eur J Gynaecol Oncol 38(4): 529-532, 2017. DOI: 10.12892/ejgo3307.2017

53 Bahl C, Singh N, Behera D and Sharma S: Association of polymorphisms in dickopff (dkk) gene towards modulating risk for lung cancer in north indians. Future Oncology 13(3): 213 232, 2017. PMID: 27640551. DOI: 10.2217/fon-2016-0117

54 Wu J, Zhang J, Zhan Z, Cao Q and Li Z: Genetic variations of dickkopf family genes might not be associated with gastric cancer susceptibility. BMC Gastroenterol 16(1): 78, 2016. PMID: 27457487. DOI: 10.1186/s12876-016-0489-1

55 Kobayashi K, Ouchida M, Tsuji T, Hanafusa H, Miyazaki M, Namba M, Shimizu N and Shimizu K: Reduced expression of the reic/dkk-3 gene by promoter-hypermethylation in human tumor cells. Gene 282(1-2): 151-158, 2002. PMID: 11814687. DOI: $10.1016 / \mathrm{s} 0378-1119(01) 00838-1$

56 Parine NR, Azzam NA, Shaik J, Aljebreen AM, Alharbi O, Almadi MA, Alanazi M and Khan Z: Genetic variants in the wnt signaling pathway are protectively associated with colorectal cancer in a saudi population. Saudi J Biol Sci 26(2): 286-293, 2019. PMID: 31485167. DOI: 10.1016/j.sjbs.2018.05.018

57 Mizobuchi Y, Matsuzaki K, Kuwayama K, Kitazato K, Mure H, Kageji $\mathrm{T}$ and Nagahiro S: Reic/dkk-3 induces cell death in human malignant glioma. Neuro Oncol 10(3): 244-253, 2008. PMID: 18443132. DOI: 10.1215/15228517-2008-016

58 Hsieh SY, Hsieh PS, Chiu CT and Chen WY: Dickkopf-3/reic functions as a suppressor gene of tumor growth. Oncogene 23(57): 9183-9189, 2004. PMID: 15516983. DOI: 10.1038/sj.onc. 1208138

59 Tsuji T, Nozaki I, Miyazaki M, Sakaguchi M, Pu H, Hamazaki $\mathrm{Y}$, Iijima $\mathrm{O}$ and Namba M: Antiproliferative activity of reic/dkk3 and its significant down-regulation in non-small-cell lung carcinomas. Biochem Biophys Res Commun 289(1): 257-263, 2001. PMID: 11708809. DOI: 10.1006/bbrc.2001.5972

60 Shien K, Tanaka N, Watanabe M, Soh J, Sakaguchi M, Matsuo K, Yamamoto H, Furukawa M, Asano H and Tsukuda K: Anticancer effects of reic/dkk-3-encoding adenoviral vector for the treatment of non-small cell lung cancer. PLoS One 9(2): e87900, 2014. PMID: 24498395. DOI: 10.1371/journal.pone.0087900

61 Hoang BH, Kubo T, Healey JH, Yang R, Nathan SS, Kolb EA, Mazza B, Meyers PA and Gorlick R: Dickkopf 3 inhibits invasion and motility of saos- 2 osteosarcoma cells by modulating the wnt-beta-catenin pathway. Cancer Res 64(8): 2734-2739, 2004. PMID: 15087387. DOI: 10.1158/00085472.can-03-1952

62 Li X, Xu Y, Chen Y, Chen S, Jia X, Sun T, Liu Y, Li X, Xiang $\mathrm{R}$ and $\mathrm{Li} \mathrm{N}$ : Sox 2 promotes tumor metastasis by stimulating epithelial-to-mesenchymal transition via regulation of wnt/betacatenin signal network. Cancer Lett 336(2): 379-389, 2013. PMID: 23545177. DOI: 10.1016/j.canlet.2013.03.027

63 Saeb-Parsy K, Veerakumarasivam A, Wallard MJ, Thorne N, Kawano Y, Murphy G, Neal DE, Mills IG and Kelly JD: Mt1mmp regulates urothelial cell invasion via transcriptional regulation of dickkopf-3. Br J Cancer 99(4): 663-669, 2008. PMID: 18665176. DOI: 10.1038/sj.bjc.6604513 
64 Wang Z, Ma LJ, Kang Y, Li X and Zhang XJ: Dickkopf-3 (dkk3) induces apoptosis in cisplatin-resistant lung adenocarcinoma cells via the wnt/beta-catenin pathway. Oncol Rep 33(3): 1097-1106, 2015. PMID: 25573172. DOI: 10.3892/or.2014.3704

65 Kawasaki K, Watanabe M, Sakaguchi M, Ogasawara Y, Ochiai K, Nasu Y, Doihara H, Kashiwakura Y, Huh NH, Kumon H and Date H: Reic/dkk-3 overexpression downregulates pglycoprotein in multidrug-resistant mcf7/adr cells and induces apoptosis in breast cancer. Cancer Gene Ther 16(1): 65-72, 2009. PMID: 18654608 . DOI: $10.1038 /$ cgt.2008.58

66 Folkman J: Tumor angiogenesis: Therapeutic implications. N Engl J Med 285(21): 1182-1186, 1971. PMID: 4938153. DOI: 10.1056/NEJM197111182852108

67 Chen T, Karamariti E, Hong X, Deng J, Wu Y, Gu W, Simpson $\mathrm{R}$, Wong $\mathrm{MM}, \mathrm{Yu} \mathrm{B}$ and $\mathrm{Hu} \mathrm{Y}$ : Dkk3 (dikkopf-3) transdifferentiates fibroblasts into functional endothelial cellsbrief report. Arterioscler Thromb Vasc Biol 39(4): 765-773, 2019. PMID: 30816803. DOI: 10.1161/ATVBAHA.118.311919

68 Issa Bhaloo S, Wu Y, Le Bras A, Yu B, Gu W, Xie Y, Deng J, Wang Z, Zhang Z and Kong D: Binding of dickkopf-3 to cxcr7 enhances vascular progenitor cell migration and degradable graft regeneration. Cir Res 123(4): 451-466, 2018. PMID: 29980568. DOI: $10.1161 /$ CIRCRESAHA.118.312945

69 Smalley MJ and Dale TC: Wnt signalling in mammalian development and cancer. Cancer Metastasis Rev 18(2): 215-230, 1999. PMID: 10728985. DOI: 10.1023/a:1006369223282

70 Krupnik VE, Sharp JD, Jiang C, Robison K, Chickering TW, Amaravadi L, Brown DE, Guyot D, Mays G and Leiby K: Functional and structural diversity of the human dickkopf gene family. Gene 238(2): 301-313, 1999. PMID: 10570958. DOI: 10.1016/s0378-1119(99)00365-0

71 Brott BK and Sokol SY: Regulation of wnt/lrp signaling by distinct domains of dickkopf proteins. Mol Cell Biol 22(17): 6100-6110, 2002. PMID: 12167704 . DOI: $10.1128 / \mathrm{mcb} .22 .17 .6100-6110.2002$

$72 \mathrm{Wu}$ C, Zeng Q, Blumer KJ and Muslin AJ: Rgs proteins inhibit xwnt-8 signaling in xenopus embryonic development. Development 127(13): 2773-2784, 2000. PMID: 10851124.

73 Mao B, Wu W, Davidson G, Marhold J, Li M, Mechler BM, Delius H, Hoppe D, Stannek P, Walter C, Glinka A and Niehrs C: Kremen proteins are dickkopf receptors that regulate wnt/beta-catenin signalling. Nature 417(6889): 664-667, 2002. PMID: 12050670 . DOI: $10.1038 /$ nature 756

74 Mao B and Niehrs C: Kremen2 modulates dickkopf2 activity during wnt/lrp6 signaling. Gene 302(1-2): 179-183, 2003. PMID: 12527209. DOI: 10.1016/s0378-1119(02)01106-x

75 Wang K, Zhang Y, Li X, Chen L, Wang H, Wu J, Zheng J and $\mathrm{Wu} \mathrm{D}$ : Characterization of the kremen-binding site on dkk1 and elucidation of the role of kremen in dkk-mediated wnt antagonism. J Biol Chem 283(34): 23371-23375, 2008. PMID: 18502762. DOI: $10.1074 /$ jbc.M802376200

76 Nakamura RE and Hackam AS: Analysis of dickkopf3 interactions with wnt signaling receptors. Growth Factors 28(4): 232-242, 2010. PMID: 20370576. DOI: 10.3109/08977191003738832

77 Caricasole A, Ferraro T, Iacovelli L, Barletta E, Caruso A, Melchiorri D, Terstappen GC and Nicoletti F: Functional characterization of wnt7a signaling in pc12 cells: Interaction with a fzd $5 \mathrm{x}$ lrp6 receptor complex and modulation by dickkopf proteins. J Biol Chem 278(39): 37024-37031, 2003. PMID: 12857724. DOI: $10.1074 /$ jbc.M300191200
78 Winston JT, Strack P, Beer-Romero P, Chu CY, Elledge SJ and Harper JW: The SCFbeta-TRCP-ubiquitin ligase complex associates specifically with phosphorylated destruction motifs in IkappaBalpha and beta-catenin and stimulates IkappaBalpha ubiquitination in vitro. Genes Dev 13(3): 270-283, 1999. PMID: 9990852. DOI: 10.1101/gad.13.3.270

79 Kawano Y, Kitaoka M, Hamada Y, Walker MM, Waxman J and Kypta RM: Regulation of prostate cell growth and morphogenesis by dickkopf-3. Oncogene 25(49): 6528-6537, 2006. PMID: 16751809. DOI: 10.1038/sj.onc.1209661

80 Agnihotri S, Wolf A, Munoz DM, Smith CJ, Gajadhar A, Restrepo A, Clarke ID, Fuller GN, Kesari S, Dirks PB, McGlade CJ, Stanford WL, Aldape K, Mischel PS, Hawkins C and Guha A: A gata4-regulated tumor suppressor network represses formation of malignant human astrocytomas. J Exp Med 208(4): 689-702, 2011. PMID: 21464220. DOI: 10.1084/jem.20102099

81 Pei Y, Yao Q, Yuan S, Xie B, Liu Y, Ye C and Zhuo H: Gata4 promotes hepatoblastoma cell proliferation by altering expression of mir125b and dkk3. Oncotarget 7(47): 77890-77901, 2016. PMID: 27788486. DOI: 10.18632/oncotarget.12839

82 Pei Y, Tang Z, Cai M, Yao Q, Xie B and Zhang X: The e2f3/mir$125 \mathrm{a} / \mathrm{dkk} 3$ regulatory axis promotes the development and progression of gastric cancer. Cancer Cell Intl 19(1): 212, 2019. PMID: 31423109. DOI: 10.1186/s12935-019-0930-y

83 Ochiai K, Morimatsu M, Kato Y, Ishiguro-Oonuma T, Udagawa C, Rungsuriyawiboon O, Azakami D, Michishita M, Ariyoshi Y and Ueki H: Tumor suppressor reic/dkk-3 and co-chaperone sgta: Their interaction and roles in the androgen sensitivity. Oncotarget 7(3): 3283, 2016. PMID: 26658102. DOI: 10.18632/ oncotarget.6488

84 Kashiwakura Y, Ochiai K, Watanabe M, Abarzua F, Sakaguchi M, Takaoka M, Tanimoto R, Nasu Y, Huh N-h and Kumon H: Down-regulation of inhibition of differentiation-1 via activation of activating transcription factor 3 and smad regulates reic/dickkopf-3-induced apoptosis. Cancer Res 68(20): 83338341, 2008. PMID: 18922905. DOI: 10.1158/0008-5472.CAN08-0080

85 Tanimoto R, Abarzua F, Sakaguchi M, Takaishi M, Nasu Y, Kumon $\mathrm{H}$ and Huh N-H: Reic/dkk-3 as a potential gene therapeutic agent against human testicular cancer. Int J Mol Med 19(3): 363-368, 2007. PMID: 17273781.

86 Kawasaki K, Watanabe M, Sakaguchi M, Ogasawara Y, Ochiai K, Nasu Y, Doihara H, Kashiwakura Y, Huh N and Kumon H: Reic/dkk-3 overexpression downregulates p-glycoprotein in multidrug-resistant mcf7/adr cells and induces apoptosis in breast cancer. Cancer Gene Ther 16(1): 65-72, 2009. PMID: 18654608. DOI: $10.1038 /$ cgt.2008.58

87 Uchida D, Shiraha H, Kato H, Nagahara T, Iwamuro M, Kataoka J, Horiguchi S, Watanabe M, Takaki A and Nouso K: Potential of adenovirus-mediated reic/dkk-3 gene therapy for use in the treatment of pancreatic cancer. J Gastroenterol Hepatol 29(5): 973-983, 2014. PMID: 24372695. DOI: 10.1111/jgh.12501

88 Shimazu Y, Kurozumi K, Ichikawa T, Fujii K, Onishi M, Ishida $\mathrm{J}$, Oka T, Watanabe $\mathrm{M}$, Nasu $\mathrm{Y}$ and Kumon $\mathrm{H}$ : Integrin antagonist augments the therapeutic effect of adenovirusmediated reic/dkk-3 gene therapy for malignant glioma. Gene Ther 22(2): 146-154, 2015. PMID: 25394252. DOI: $10.1038 /$ gt.2014.100

89 Than SS, Kataoka K, Sakaguchi M, Murata H, Abarzua F, Taketa C, Du G, Yashiro M, Yanagihara K and Nasu Y: Intraperitoneal 
administration of an adenovirus vector carrying reic/dkk-3 suppresses peritoneal dissemination of scirrhous gastric carcinoma. Oncol Rep 25(4): 989-995, 2011. PMID: 21249317. DOI: $10.3892 /$ or.2011.1149

90 Hirata T, Watanabe M, Kaku H, Kobayashi Y, Yamada H, Sakaguchi M, Takei K, Huh N-H, Nasu Y and Kumon H: Reic/dkk-3-encoding adenoviral vector as a potentially effective therapeutic agent for bladder cancer. Int J Oncol 41(2): 559-564, 2012. PMID: 22665039. DOI: 10.3892/ijo.2012.1503

91 Tanaka E, Uchida D, Shiraha H, Kato H, Oyama A, Iwamuro M, Watanabe M, Kumon $\mathrm{H}$ and Okada $\mathrm{H}$ : Promising gene therapy using an adenovirus vector carrying reic/dkk-3 gene for the treatment of biliary cancer. Curr Gene Ther 20(1): 64-70, 2020. PMID: 32148193. DOI: 10.2174/1566523220666200309125709

92 Watanabe M, Nasu Y and Kumon H: Adenovirus-mediated reic/dkk-3 gene therapy: Development of an autologous cancer vaccination therapy. Oncol Lett 7(3): 595-601, 2014. PMID: 24527065. DOI: 10.3892/ol.2013.1777

93 Suzawa K, Shien K, Peng H, Sakaguchi M, Watanabe M, Hashida S, Maki Y, Yamamoto H, Tomida S and Soh J: Distant bystander effect of reic/dkk3 gene therapy through immune system stimulation in thoracic malignancies. Anticancer Res 37(1): 301307, 2017. PMID: 28011506. DOI: 10.21873/anticanres.11321
94 Naume B and Espevik T: Effects of il-7 and il-2 on highly enriched cd56+ natural killer cells. A comparative study. J Immunol 147(7): 2208-2214, 1991. PMID: 1717551.

95 Sakaguchi M, Kataoka K, Abarzua F, Tanimoto R, Watanabe M, Murata H, Than SS, Kurose K, Kashiwakura Y and Ochiai K: Overexpression of reic/dkk-3 in normal fibroblasts suppresses tumor growth via induction of interleukin-7. J Biol Chem 284(21): 1423614244, 2009. PMID: 19279003. DOI: 10.1074/jbc.M808002200

96 Kardooni H, Gonzalez-Gualda E, Stylianakis E, Saffaran S, Waxman $\mathrm{J}$ and Kypta RM: Crispr-mediated reactivation of $\mathrm{dkk} 3$ expression attenuates tgf- $\beta$ signaling in prostate cancer. Cancers 10(6): 165, 2018. PMID: 29843383. DOI: 10.3390/cancers 10060165

Received September 15, 2020

Revised September 28, 2020

Accepted September 29, 2020 